\title{
Head teachers' professional management needs and concerns: Evidence from an educational district in Ghana
}

\author{
Peter Lonyian Suaka ${ }^{1}$ and Alfred Kuranchie ${ }^{2 \star}$ \\ ${ }^{1}$ Ghana Education Service, Tano North District, Tanoso-Sunyani, Ghana. \\ ${ }^{2}$ Faculty of Education, Catholic University College of Ghana, Sunyani, Ghana.
}

Accepted 14 March, 2018

\begin{abstract}
The study explored the head teachers' professional needs in school management. The qualitative study was underpinned by the interpretive philosophical thought. It employed a case study approach and collected data using interview guide. Purposive sampling technique was employed to select 15 head teachers and 6 circuit supervisors to participate in the exercise. The study revealed that the head teachers were not unaware of the managerial skills they needed to proficiently manage their schools. However, the participants seemed to have a need in executing staff personnel services, financial and business management and schoolcommunity relationship roles. The participants also had concerns with respect to lack of pre-headship training, lack of needs assessment prior to in-service training programmes, inadequate continuous professional development programmes and lack of authority to sanction staff. The head teachers and circuit supervisors, therefore, unanimously called for pre-headship and in-service training programmes respectively for aspiring and serving head teachers to equip them with the requisite competencies for headship duties. The participants believed that continuous professional development programmes have the capacity to update and upgrade head teachers' knowledge and skills to enhance their professional growth and development.
\end{abstract}

Keywords: Head teachers, professional and management needs, issues and concerns, pre-headship training, continuous professional development.

*Corresponding author. E-mail: kuranchiealf@yahoo.com.

\section{INTRODUCTION}

The nature of work in post-industrial society is changing rapidly and significantly and the change affects the role of educational leadership. Understanding the role and nature of preparation for leadership must be based on recognition of how work is defined and organized in the $21^{\text {st }}$ century (Mulford, 2003). There is an increasing consensus among researchers in the field of educational leadership and management in both advanced and developing countries that the leadership provided by head teachers is absolutely crucial for schools (Bush and Jackson, 2003). Headship roles are thus reckoned to be a quintessential factor in school success. Zame et al. (2008) contend that leadership is a key item in $21^{\text {st }}$ century organizations such as schools. Several scientific investigations have also unveiled that quality education depends primarily on the way schools are managed, more than on the abundance of available resources and the capacity of schools to improve teaching and learning is strongly influenced by the quality of leadership provided by the heads (De Grauwe, 2000 quoted in Simkins et al., 2003). According to lbukun et al. (2011), maintaining quality and standards in education depends largely on the extent to which heads of schools effectively execute their leadership responsibilities. Heads of schools owe it a duty to establish, monitor and maintain quality and standards in education (Esia-Donkoh, 2014). 
This makes it expedient for heads of schools to be adequately prepared to enable them to carry out their functions exquisitely.

Despite the importance of headship to school success, the procedures used in appointing and offering preservice training, induction and in-servicing training for head teachers are inappropriate in many developing countries, especially those in the continent of Africa (Bush and Oduro, 2006). Globally, the majority of school heads do not receive training prior to assumption of office. The heads perform the work from experience (Balansikat and Gerhard, 2005 as cited in Kayiwa, 2011). This is not a good development in a constantly changing society where new things require new knowledge and skills to perform professional and administrative duties.

However, in some countries such as Hungary, Lithuania, Catalonia and Slovenia, specific training is required of teachers prior to appointment as school heads (Balansikat and Gerhard, 2005 as cited in Kayiwa, 2011). Again, in countries like UK and Switzerland, prospective heads are given training in school management (Kayiwa, 2011). The Latin American countries and the Caribbean regions also recognize that there is a need to effectively prepare school principals to enhance their role in the realization of the aims of the various education reforms being carried out (Borden, 2002). The countries which provide training for prospective heads recognize the fact that it is not all teachers who have management and administration backgrounds that they need to efficiently and effectively perform their headship duties. Consequently, prospective head teachers are offered training to sufficiently prepare them for headship obligations.

The Ghanaian educational system has gone through a metamorphosis with the view to improving all aspects and levels of education. The last major educational reform was experienced in Ghana in 1987 which brought about the Junior Secondary School (JSS) concept with the aim of improving quality of education. However, little emphasis was laid on preparation and development of head teachers. It was not until the introduction of the 'Free Compulsory and Universal Basic Education (FCUBE)' programme that importance was attached to the improvement of efficiency of school management (Zame et al., 2008). The FCUBE policy requires head teachers to receive training in school management (Ghana Education Service (GES), 2001) to enable them to perform their tasks effectively. It also recommends the formation of School Management Committees (SMCs), Governing Bodies and Parent-Teacher Associations (PTAs) by individual schools for them to work hand-inhand with the heads, and guide them in school policy formulation (GES, 2001). Also, the Ministry of Education (MoE) and GES produced a Head teachers' Handbook in 1994 to facilitate the performance of heads' role in quality education provision (Oduro, 2003).

Head teachers are expected to perform a wide range of duties to ensure that effective teaching and learning take place in their schools to achieve the set goals and objectives (Ghana Education Service, 2010a, b). Head teachers certainly need some competencies to be able to leave above reproach.

\section{Problem statement}

Ghana as a developing country, over the last decades, has been making frantic efforts to improve its education system, in particular, to contribute to the wider national development. The current Junior High School (JHS) system constitutes a three-year post-primary education which replaced the earlier four-year middle school system. This structural development of the educational system was aimed to provide good quality basic education to children of school-going age.

The changes in the education system in Ghana require highly-developed leaders with appropriate management abilities. Head teachers are perceived as the principal instrument (Report of the President's Committee on Review of Education Reforms in Ghana (RPCRERG), 2002) through whom leadership and management are carried out in schools. Head teachers make a difference so they ought to be trained prior to assumption of duty. They also need to enjoy continuous professional development to position them to help improve standards of education and students' performance. However, there is no provision of formal pre-service training (PRESET) for head teachers (Oduro and MacBeath, 2003; Oplatka, 2004; Bush and Oduro, 2006). Although all trainee teachers attend teacher training colleges (TTCs), there are no specific courses for those aspiring to be head teachers. Yet on completion of their programmes, some of them receive direct appointments to leadership and management positions in schools, especially in rural areas (Oduro, 2003). Again, although some universities in Ghana like the Catholic University College of Ghana offer programmes in school administration, the graduates are not likely to become head teachers within any short period of service. In most cases, it is the experienced and long-serving teachers who are favoured for headship positions. A research carried out by Bush and Oduro (2006) unveiled that most heads were appointed without any specific management training and only a few of them received appropriate in-service training following their appointment. A survey conducted in Accra also revealed that the head teachers lacked leadership proficiency due to the absence of leadership preparation programmes (Zame et al., 2008).

The lack of emphasis on developing leadership and management skills of school heads is one of the greatest challenges to the successful implementation of government's quality basic education policy in Ghana. A review of the education system in Ghana indicates that many of the problems that the schools faced are linked to 
leadership and management issues. These problems include: inadequate preparation and training of heads; heads combining management with teaching at the basic level; leaving them with a little or no time for management and supervision; poor supervision by heads; insufficient authority of heads teachers and lack of commitment on the part of heads and teachers (RPCRERG, 2002).

These management problems draw attention to the need for proper training of head teachers to enable them to cope with changes and challenges in the education system. However, there seemed to be no study that has explored the needs and concerns of head teachers, which could be considered in preparing teachers to take a leadership position in schools. This study, therefore, sought to fill this gap by gathering data from heads of schools and their immediate supervisors to establish head teachers' professional management needs.

\section{Research objectives}

The study had two main rationales, which are:

1. To explore the management needs of head teachers of basic schools.

2. To unravel concerns of head teachers in the management of schools.

\section{LITERATURE REVIEW}

\section{Roles of head teachers}

Schools, like all other organizations, are steered by leaders. School leaders perform pivotal roles in making schools very effective (Townsend, 2007). According to Atta et al. cited in Esia-Donkoh (2014) and Ojo and Olaniyan (2008), the duties of school heads include planning, staff personnel services, pupils personnel services, curriculum and instructional development, improvement and appraisal, financial and business management, maintenance of school-community relationship and general tasks.

Head teachers are expected to manage and control schools. As lower level managers of the education service, they plan some activities mostly with their staff for the progress of the schools. Planning is very essential as it aids to find the philosophy, policies, programmes, procedures, practices and challenges of institutions (Ojo and Olanyan, 2008). As a saying goes, if one fails to plan, he/she plans to fail. Head teachers, therefore, need good knowledge and skills in planning to effectively lead their schools.

Staff personnel services involve identifying staff needs of the school and attracting competent ones to fill the vacancies. The head teacher is also supposed to create good conditions for teachers to work and also ensure their professional growth and development (Esia-Dinkoh, 2014). Head teachers need to work with others to improve on the professional competence of teachers. As part of their duties, head teachers in collaboration with education officers and other experts organize in-service training (INSET) and other programmes to upgrade and update the knowledge and skills of teachers in both methodology and subject matter contents. They perform this function to build the capacities of teachers to enable them to be alive with their responsibilities. Staff personnel function also entails assigning duties to teachers, supervising, motivating, supporting and rewarding them as well as sanctioning recalcitrant teachers. They also monitor and evaluate the quality of instructions in the schools. They create a positive and caring ethos for effective teaching and learning to take place. They also involve teachers in decision making as well as delegating responsibilities to their subordinates. Head teachers also supply information on new policies, guidelines and programmes from authorities to enable teachers to perform their jobs.

Pupils personnel services concern admitting and managing pupils in the school. The heads of schools select and place pupils in appropriate classes and also offer guidance and counseling services to learners (Ojo and Olanyan, 2008). Heads of schools also owe it a duty to provide an effective, safe and secured learning environment and conditions for the pupils entrusted in their care. The head teachers need to ensure that pupils' physical and health needs are met. In boarding schools, they organize house staff to ensure the welfare of the pupils. Furthermore, the heads are obligated to maintain discipline in schools. They are also expected to promote extra-curricular activities in the schools to contribute to the total development of pupils.

Head teachers also play roles in curriculum and instructional development, improvement and appraisal services. This role concerns planning, implementing, supervising and evaluating what pupils are to learn (EsiaDonkoh, 2014). This role of the head is very essential as the school exists to ensure good pupils' learning outcomes. Dipaola and Hoy (2008) contend that supervision is very vital to improving students' academic achievement. A study also found that effective supervision of teaching and learning enhances students' performance (Too et al., 2012). So the head teacher has the crucial responsibility to ensure effective working of the school (Birgen, 2007). To achieve this, head teachers are obliged to supervise the supply of instructional materials for teachers and pupils' use in their schools.

Heads of schools also perform financial and business management functions. According to Van and Wachowisz (2005), financial management is concerned with the acquisition, financing and management of assets to achieve the overall goals in mind. There are public sector financial laws and regulations on the financial administration of educational institutions in Ghana. The 
laws and regulatory framework include the 1992 Constitution of the Republic of Ghana, Article 187 (2, 3, 4 and 5) and the Financial Administration Act (2003), Act 654 (FAA). Heads of schools are to plan and use funds prudently to engender efficient running of the institutions. With the introduction of capitation grant, heads of schools are obliged to keep records of receipts and payments to be reviewed by the School Management Committee (SMC), the District Education Office and the District Auditor. Again, monthly, quarterly and annual financial reports are prepared on fund use and monitoring functions are performed by various regional and district officials as well as half-yearly audits (Public Procurement Act-Act 663 of 2003, Ampratwum and Armah-Attoh, 2010). GES entrusts head teachers with these responsibilities yet the heads are not trained for that task (Dadey, 1990 cited in Harber and Davies, 2002; Oduro and MacBeath, 2006).

Head teachers are also supposed to help create and maintain a school-community relationship. Esia-Donkoh (2014) contends that schools succeed when there is a good relationship within them and their relevant publics. Therefore, schools need to have a good rapport with the communities where they are located as well as their agencies. To Fullan (2001), school leaders play a vital role in strengthening the link between schools and communities and their agencies.

Besides the above functions, head teachers perform some general functions for effective running of their schools. The functions include attending meetings, handling interpersonal situations, handling correspondence and attending school functions.

While some of the duties performed by head teachers directly impact on pupils' academic achievement, others indirectly affect learning outcomes. In an apparent support of this view, Cheng (2002) postulates that although it is the teachers' output that directly impacts on students' learning outcomes the quality of leadership cannot be discounted in influencing teacher motivation and quality of teaching which takes place in schools.

\section{Appointment and training of heads of schools}

Different criteria are used for recruiting and selecting head teachers in different countries. Research has consistently shown that having a structured approach to the appointment of head teachers has the tendency to increase the validity of recruitment and selection of school leaders (Middlewood, 1997). RPCRERG (2002) notes that the authority for appointing head teachers is vested with the Directors of Education (DoE) of various districts, although they manage education with the support of the Assistant Directors in charge of specific schedules and the regional managers of education units of religious organizations. The governing bodies have no role in the appointment of head teachers. Bush and
Oduro (2006) indicated that in Ghana two approaches are used by GES to appoint head teachers. The first is the appointment through direct posting, which involves appointing newly-trained teachers to lead schools, especially in the rural areas. The unattractiveness of rural life appears to have made working in rural schools noncompetitive among teachers, who might otherwise have had aspirations to be appointed as head teachers. The second strategy is appointment through selection interviews, which is largely associated with the appointment of head teachers in urban schools. In this situation, candidates for interviews are selected through recommendations by senior officers (Bush and Oduro, 2006).

Some developing countries also appoint head teachers on the basis of experience, in addition to some other criteria. Lahui-Ako (2001) indicates that in Papua New Guinea, inspection reports form the basis of promoting experienced teachers into headship positions, but this procedure is characterized by favoritism. A similar situation prevails in some other African countries where the appointment is done without recourse to relevant training. In those countries, no formal training or qualification is considered for headship post but rather long-serving and experienced teachers are normally appointed to such positions (Oduro, 2003; Bush and Oduro, 2006). Essentially, aspiring head teachers' knowledge in administration, management and leadership, financial issues, among others, is not a prerequisite in the appointment of heads in those jurisdictions. Meanwhile, evidence from different countries and sources indicate that school leaders need specific training in order to perform their various responsibilities well (Pont et al., 2008). However, in the United Kingdom, the National Professional Qualification for Head teachers (NPQH) course has been introduced for aspiring head teachers. In that country, candidates for headship position are also selected by the governing bodies in a competitive manner.

The preparation of aspiring head teachers is highly recognized in most advanced countries because of the importance of headship in school improvement and effectiveness (Bush, 1998). Also, some developing countries such as Hong Kong and some South East Asian countries such as Malaysia and Singapore have PRESET for head teachers (Bush and Jackson, 2003; Wong, 2005). Middlewood (1997) indicates that in Canada principals are required to undergo appropriate training to obtain relevant qualification and be allocated to schools or colleges for a specific period before being reposted to different schools to head. These countries recognize the need for aspiring and practising head teachers to be equipped with the knowledge, skills and values required to perform their professional and administrative functions. This underscores the need for induction and in-service training for head teachers (Kuranchie, 2015). 


\section{METHODOLOGY}

\section{Study type}

The study employed qualitative research method using interviews to collect data on head teachers' management needs and concerns. Seidu (2007) explains that qualitative research emphasizes the holistic description of whether it is being observed rather than comparing the effects of a particular treatment. The choice of this approach is in line with assumptions underlining knowledge construction. Moreover, this approach allowed the use of multiple sources of data from head teachers and circuit supervisors for triangulation purposes (Kuranchie, 2016).

\section{Population and sample}

The head teachers and circuit supervisors of the Tano North district of the Brong Ahafo region of Ghana constituted the target population. Since the head teachers are officially mandated to superintend over the schools, they could come up with the requisite skills they did or did not have to perform their duties exquisitely. They also had the capacity to know issues bordering their work. The circuit supervisors were also included in the study because they supervised the heads of schools and appraised them intermittently. The inclusion of the circuit supervisors was for triangulation purpose.

The purposive sampling method was employed to select the participants for the study. Both the head teachers and circuit supervisors who had served for more than five years in their various capacities qualified for inclusion in the study. The number of years served in that capacity was used as a selection criterion because the participants with that number of years of headship would have amassed a lot of experience to provide credible data relevant to the research. In all, 15 head teachers and 6 circuit supervisors met the inclusion criterion and were contacted for the exercise.

\section{Research Instrument}

As a qualitative study, semi-structured interviews were conducted with the head teachers and supervisors to unravel head teachers' professional needs in the management of Junior High Schools. The instrument was deemed appropriate to help achieve the two-fold purposes of the research. One set of interview guide was designed to gather data from the two categories of participants. The instrument had both close and open ended items. The instrument was in three parts which are Section "A": Demographic factors of participants, Section: "B": Head teachers' management needs and Section: "C": Concerns of the participants. The instrument was validated via expert judgment. The instrument was scrutinized by a research expert and an educational leadership lecturer to improve on face and content validity. The responses were written on a notepad, which was expanded prior to analysis. The triangulation aided in ensuring trustworthiness of the responses.

\section{DISCUSSION}

The results of the research are presented thematically. The results are presented based on the issues which underpinned the research in three sections. Section "A" presents results on the bio-data of the participants, Section "B" covers head teachers' responses and Section "C" presents circuit supervisors' responses.

\section{Section A: Demographic factors of participants}

The research shows that most of the head teachers were advance in age. None of them was less than 30 years. In terms of professional qualifications, the majority of the head teachers held Diploma in Education while a few of them held Bachelor's degrees in Education. Their length of service varied from 16 to 30 years and they had served between 6 and 15 years as head teachers.

The qualifications of the circuit supervisors were not different from the head teachers. Most of them had Diploma and Bachelor's degree in Education. Their length of service as circuit supervisors ranged from 5 to 15 years and they had reached the ranks of Assistant Director.

It is gleaned from the demographic data that both head teachers and circuit supervisors have held their respective positions for long and had good experience and insights to provide credible information for the research.

\section{Section B: Head teachers' responses}

\section{Appointment and pre-headship training}

On the process of appointment, most of the head teachers indicated that when the vacancies were advertised via circulars from the District Directorate of Education, they applied and attended interview. It is only two of them who indicated that they did not attend an interview. They explained that when their predecessors retired, they were asked to take over.

With respect to enjoying induction prior to assumption of duty as heads, several of the head teachers responded in the negative. They indicated that they did not receive induction when appointed to head the schools. They assumed duty straightaway without undergoing formal induction. A head teacher said I even started working as a head before my appointment letter was handed over to me. 
However, three head teachers reported that they were made to understudy their heads who were about to go on retirement. The education office asked them to assist and understudy their heads and that constituted an induction, in their view. One of them said, the period provided me the opportunity to learn a lot about headship. My head directed me to do virtually everything during the two terms that I understudied her.

\section{Management needs of head teachers}

The head teachers first identified planning, organising, facilitation, and monitoring and evaluation skills as what they needed to function effectively to achieve educational goals and objectives. They contended that without these skills one would not be able to effectively steer the affairs of a school.

On planning needs, most of the head teachers indicated that they did not have a challenge with. They did not face planning challenges in the management of activities of the schools. They explained that most of the things they had to do are usually sent to them from the district, regional and national education directorates. A head teacher said at the beginning of every academic year, schools are told what to do, so the few things you have the right to do are minor, which are less difficult to plan, especially if you have more experienced teachers on staff to assist you.

The general response of the head teachers shows that the educational system is still highly centralized. So the decentralization concept is not working fully in the education sector to give heads of schools much autonomy to plan certain things at their level.

On staff personnel service, the head teachers reported that they did not have a need for. Most of the heads indicated that they have been performing that effectively. They added that monitoring and supervising staff are a function they have been carrying out competently. A head teacher expressed I have been doing this work very well except that I don't wield the power to sanction wayward staff. We are limited when it comes to matters of this nature. It is the education office, which has the power to sanction teachers. Meanwhile, most often, the officers fail to do the needful when you report recalcitrant teachers to them.

Some head teachers also admitted that even when they had the authority to discipline their subordinates they were unable to do that due to familiarity culture. As they were once colleague teachers in the same schools, they found it difficult to bring them to order when there was something wrong. As four head teachers shared it's difficult to reprimand someone you were with as a colleague teacher. Another head teacher said my teachers still regard me as a colleague and always ask me what I used to do when I was an ordinary teacher in the school.

With pupils' personnel service, the head teachers reported that they did not have a need for. Several of the head teachers indicated that they had been performing that function exquisitely in their schools. According to them, they had really been providing a safe learning environment for pupils. They also indicated that they always ensured that the physical and health needs of their pupils were met. A head teacher said when resources are available, my school ensures that the pupils are safe and secured. Even in difficult times, we endeavour to do the little we can to ensure that our children are not at risk.

With respect to curriculum and instructional development, improvement and appraisal function, the head teachers seemed to have a need for. They reported that they did not have the competence to appraise the curriculum. They explained that although the curriculum was developed and sent to the schools, they ought to appraise it from time to time but they did not have the well withal to do it. As two head teachers retorted, do we have the know-how, skills and power to determine what pupils have to learn or change anything in the syllabus? We only ensure that teachers teach what the authorities bring to us. Even when you detect something wrong with an aspect of the curriculum and report, nothing is done about it.

Another management role that the head teachers seemed to have a need for is financial and business management. Most of the head teachers lamented that they fumbled when they had to prepare financial returns. Three head teachers shared that with the introduction of capitation grant which requires monthly, quarterly and annual reporting; heads are grappled with a huge task. Those of us without Accounting background always have to seek help elsewhere, they added.

Five head teachers said we always ask our teachers who studied Accounting at school to prepare the accounts for us. They allowed their teachers to prepare financial returns to avoid audit queries. Another head teacher stated due to my little knowledge in Accounting, I always receive audit query. And l've gained a bad name in the eyes of the audit unit.

The head teachers' responses mean that they did not have adequate knowledge in Financial Accounting and Management to perform that function satisfactorily. Until head teachers are trained in Financial Accounting and Management, they may not be able to perform this headship role effectively.

Finally, the head teachers seemed to have management need in creating and maintaining a schoolcommunity relationship. The heads pointed out that there was a challenge in fostering a strong link with the communities and their agencies.

\section{Concerns of head teachers in the management of schools}

The first issue that almost all the head teachers raised 
was the lack of pre-headship training for prospective head teachers. According to them, pre-headship training was important for efficient running of schools. A head teacher expressed if the aspiring head teachers will be able to perform their tasks competently and confidently, the importance of pre-service training cannot be underestimated. They need to be equipped with the relevant competencies through pre-service training programmes. Head teachers' work becomes more difficult in the initial stages because of the absence of such programmes.

A related issue that was of a concern to the head teachers is lack of needs assessment before training programmes are organised for head teachers and teachers. They were worried that needs assessment was not conducted to elicit the needs of heads prior to organising training programmes for serving head teachers. A head teacher lamented that most of the time, no one consults you to ascertain what your needs are so as to plan a programme that will be beneficial to you. Because of that most of the trainings we attend don't give us new things. So after the training, participants would say, the same old things.

According to the head teachers, they did not have the opportunities to acquire relevant knowledge, skills and values to effectively perform their roles. The programmes rendered for them did not necessarily meet their professional and administrative needs. This, they attributed to lack of needs assessment prior to execution of training programmes. The head teachers added that the failure of education authorities to conduct needs assessment was not only restricted to training programmes for them but also those offered for their teachers.

The head teachers also raised the issue of lack of authority and power to discipline teachers. According to them, they have not been empowered by GES to discipline and sanction teachers. It is the education officers who have the authority to discipline teachers who behave inappropriately. Meanwhile, the officers often failed to take disciplinary actions against those teachers. The head teachers complained that this situation was responsible for the negative attitude of some teachers towards their work.

\section{Section C: Circuit supervisors' responses}

\section{Appointment and pre-headship training}

The circuit supervisors corroborated the head teachers' response that interested teachers who have reached the rank of principal superintendent apply and attend selection interview and successful ones are given headship position. Two circuit supervisors stated when there is a vacancy in a school, a circular is sent to all basic schools in the district to inform teachers of it. We do that to provide equal opportunity for those who are qualified to apply so that no one can blame us of partiality.

The circuit supervisors again corroborated the head teachers' response that no formal and elaborate induction is given to new head teachers prior to assumption of duty. At times, we visit the schools to offer assistance when we realize they have some difficulties in the discharge of their responsibilities, a circuit supervisor said.

\section{Management needs of head teachers}

The circuit supervisors intimated that they did not see the head teachers to have problems with planning. They also reiterated that as strategic planning of what goes on in the education system is done at the top, head teachers have less to do when it comes to planning teaching and learning activities. As a circuit supervisor said, head teachers do the only day to day planning of activities that they have to carry out to ensure achievement of the broader goals of the national curriculum. I don't see my head teachers having problems with that.

On staff personnel services, most of the circuit supervisors indicated that their head teachers did not live up to expectation. They highlighted that most of them did not ensure that their teachers went about their duties in a manner that promotes teaching and learning. Two circuit supervisors indicated that there were always lapses in head teachers' supervisory roles in the schools. According to them, the head teachers did not see to it that their teachers performed their work well. The heads only did the right things when they heard officers were coming to their schools. So when you paid an impromptu visit, you met mess in the schools, they added.

Concerning pupils personnel services, most of the circuit supervisors believed that the head teachers were not effectively and efficiently providing it. Two circuit supervisors pointed out in most of the schools, pupils don't enjoy guidance services. They are also unable to put in place measures to ensure holistic development of pupils. They only concentrate on academic work of pupils with little emphasis on non-academic gains of pupils.

On financial and business management role, the circuit supervisors lamented that most of the head teachers always had problems with. According to the officers, the head teachers mostly failed to prepare financial returns on time and correctly, used school funds inappropriately and some received audit queries. Three circuit supervisors indicated we have to be calling on the heads to prepare and submit the returns before they do that. Meanwhile, they tend to commit the same mistakes all the time.

Another circuit supervisor expressed they quickly go for the money but delay in accounting for it.

Regarding school-community relationship, the officers 
indicated that the head teachers were unable to perform the role effectively. They underscored that most of the head teachers were unable to forge a strong link with the communities and some useful agencies. A circuit supervisor said my heads have not been able to take advantage of both human and material resources in the communities because they are not in good terms with most of the key personalities in the areas.

\section{Concerns of circuit supervisors on head teachers' management of schools}

The circuit supervisors also had a concern about preheadship training for head teachers. All the circuit supervisors accepted that new head teachers did not undergo formal training prior to assumption of duty. They, however, indicated that they did receive in-service training intermittently. Two circuit supervisors expressed aspiring head teachers did not possess the competencies needed for their roles so pre-headship training is very important for them. Also, most of them did not know what the headship position entails, especially in the early stages of their position and made their work very difficult.

The circuit supervisors also raised the issue of needs assessment prior to carrying out training programmes. Two of them said before INSET programmes are organized; there was the need to determine the type of training the participants needed for effective performance.

They also complained of lack of resources and competence of the District Training Officers to organise INSETs. They substantiated that at times, they lacked the competence to carry out some INSET programmes yet they were reluctant to seeking assistance from outside.

Another issue that was a concern to the circuit supervisors is inadequate continuous professional development opportunities. They complained that head teachers are not provided an opportunity to attend programmes continuously through in-service training, seminars, symposia and short courses to be abreast of new trends in the educational enterprise in general and school leadership in particular. This situation tends to deprive head teachers of new knowledge and skills to decisively deal with new developments.

From the accounts given thus far, it is apparent that the circuit supervisors corroborated the head teachers' response that the heads of schools did not have a need for planning school activities. There was also a consensus that the head teachers had a need for staff personnel services, financial and business management and creating a school-community relationship. There was, however, a dissenting stance on pupils' personnel services. While most head teachers held the belief that they were on top of issues with respect to that role, the circuit supervisors claimed that the head teachers were inefficient in that regard.
Furthermore, both the head teachers and circuit supervisors unanimously indicated that most head teachers did not receive pre-headship training before assuming duty. They also concurred that there were not enough continuous professional development programmes to equip head teachers with the competencies needed to perform their duties. It is plausible that lack of pre-headship training and inadequate continuous professional development opportunities accounted for the head teachers' needs in most of their roles. The circuit supervisors consequently suggested that the needs of head teachers should be taken into consideration in in-service training programmes.

\section{CONCLUSION AND RECOMMENDATIONS}

The purpose of the study was to explore the management needs of head teachers. The qualitative study gathered data from head teachers and their immediate supervisors. The study unveiled that although the head teachers had ideas on essential management skills that aid them to execute their headship duties, they had a need for staff personnel services, pupils personnel services, financial and business management, and school-community relationship roles. The study also brought to light concerns such as lack of pre-headship training, lack of needs assessment prior to in-service training programmes, lack of authority and power to discipline teachers and inability to manage teachers due to familiarity culture. Appointing head teachers from existing staff appeared to affect their authority to ensure that the right things were done. The head teachers became 'helpless' when it came to management of their staff. One step towards improving the situation is empowerment, which can be done through decentralization of power and authority within GES.

It is recommended that the country emulates those which have stringent policies on pre-headship training for aspiring head teachers. Such a policy would enjoin prospective heads to go through extensive leadership training before taking up headship position. It should be made mandatory for all head teachers to undergo extensive management and leadership training before taking up headship position in schools. That would help equip them with essential competencies for the job that awaits them.

Also, GES needs to be offering continuous professional development opportunities to develop leadership and management skills of serving school heads. Induction and adequate in-service training would help direct head teachers on how they should approach their professional and administrative duties such as preparation of financial returns to show accountability, promotion of schoolcommunity relationship, managing staff to engender efficient delivery of duties; and promoting collaboration 
between school and community and its agencies.

Besides, GES needs to ensure that the in-service training programmes intended for school heads are preceded by needs assessment. This bottom-up approach would help factor in what would equip heads of schools to be alive with their responsibilities.

\section{LIMITATIONS AND SIGNIFICANCE}

Like most studies, the current study has some limitations that ought to be observed. In the first place, the schools are in only rural communities. The inclusion of schools in peri-urban and urban communities may have given a different picture of the head teachers' management needs and concerns. Again, a few participants were drawn from schools in only one educational district. The research may have yielded different findings if far more head teachers were drawn from many districts across the length and breadth of the country. Thus, the small sample size may not have helped to present a holistic and better picture of the issues studied in the country.

In addition, only primary data were gathered from the field to answer the research questions. A more comprehensive understanding of the research problem would have been attained if secondary data such as financial accounts that have been prepared by the head teachers, audit queries that head teachers might have received, queries that head teachers might have given to recalcitrant teachers and complaints about the curriculum that have been given by head teachers, among others. Finally, the study utilized only one research approach to generate qualitative data on head teachers' professional management needs and concerns. This did not aid to provide a broad-based evidence of the research problem.

In spite of the limitations however, the research contributes to knowledge, policy and practice. Firstly, the research has contributed to enhancing understanding of head teachers' professional management needs and concerns. The study is ground breaking and lays a foundation for future research. In view of the limited literature on the subject, the study would serve as a starting point for further research into the subject. The research contributes to expanding the literature on school management and leadership as well. Secondly, the research has provided data that can inform policy decision at the district education directorate. Thirdly, the research has provided empirical data that can be used to improve induction and in-service training programmes for school heads in the district. The outcomes of the study may be of immense benefit to heads of schools, supervisors and training officers. If the issues that emerged from the study are adequately addressed, it would go a long way to improve the administration of basic schools in the jurisdiction.

It is suggested that the study should be replicated in basic schools in many parts of the country and with large sample size to provide a comprehensive picture of the issues embedded in the study to inform policy decision. Also, future research on the subject needs to include schools in peri-urban and urban communities to enhance a better understanding of the issues. Again, it will be worthwhile for future research to gather secondary data as well to enrich the outcomes. Lastly, future research should combine qualitative and quantitative methods to investigate the issues to yield better and comprehensive insights.

\section{REFERENCES}

Ampratwum, E., and Armah-Attoh, D. (2010). Public expenditure tracking survey in education: Tracking capitation grant in public primary schools in Ghana. Research Paper, No 19.

Birgen, P. (2007). Strategic thinking. Principal: The merchant of knowledge. Nairobi: Image Books Publishers.

Borden, A. M. (2002). School principals in Latin America and the Caribbean: Leaders for change or subjects of change? Paper presented at the Comparative and International Education Society 46th Annual Conference, Orlando, FL March 5-9, 2002.

Bush, T. (1998). The national professional qualification for head teachers: the key to effective school leadership? School Leadership and Management, 18(3): 321-333.

Bush, T., and Jackson, D. (2003). A preparation for school leadership: International perspectives. Educational Leadership and Administration, 30(4): 417-429.

Bush, T., and Oduro, G. K. T. (2006). New principals in Africa: preparation, induction and practice. Journal of Educational Administration, 44(4): 359-375

Cheng, Y. C. (2002). Leadership and Strategy. In T. Bush and L. Bell (Eds.). The principles and practices of educational management. London: Paul Chapman Publishing Ltd.

DiPaola, M. F., and Hoy, W. K. (2008). Principals improving instruction: Supervision, evaluation, and professional development. Boston. Pearson/Allyn and Bacon.

Esia-Donkoh, K. (2014). Attaining school and educational goals: Duties of head teachers of public basic schools in Ghana. Journal of Education and Practice, 5(1): 64-72.

Fullan, M. (2001). The new meaning of educational change. $3^{\text {rd }}$ ed. New York, NY: Teachers College, Columbia University.

Ghana Education Service (2010a). Head teachers' handbook. $2^{\text {nd }}$ ed. Accra: Ministry of Education.

Ghana Education Service (2010b). School management committee resource handbook. $2^{\text {nd }}$ ed. Accra: Ministry of Education.

Ghana Education Service (GES) (2001). School management committee (SMC)/Parent teacher association (PTA) handbook: Improving quality education through community participation. Accra: Ministry of Education.

Harber, C., and Davies, L. (2002). School management and effectiveness in developing countries: The post bureaucratic schools. London: Continuum.

Ibukun, W. O., Oyewole, B. K., and Abe, T. O. (2011), Personality characteristics and principal leadership effectiveness in Ekiti State, Nigeria. International Journal of Leadership Studies, 6(2): 249-262.

Kayiwa, B. (2011). Assessment of leadership training of head teachers and secondary school performance in Mubende district, Uganda. M. A. Thesis. Bugema University, Kampala.

Kuranchie, A. (2015). The educator's guide. Kumasi: Bookworm Publications.

Kuranchie, A. (2016). Research made easy. $2^{\text {nd }}$ ed. Kumasi: Bookworm Publications.

Lahui-Ako, B. (2001). The instructional leadership behaviour of Papua New Guinea high school principals: A provincial case study. Journal of Educational Administration, 39(3): 233-265.

Middlewood, D. (1997). Managing recruitment and selection. In Bush, B. and Middlewood, D. (Eds.) Managing People in Education. 
London: Paul Chapman Publishing Ltd.

Mulford, B. (2003). Leadership for learning research group. Tasmania: University of Tasmania.

Oduro, G. K. T. (2003). Perspectives of Ghanaian head teachers on their role and professional development: The case of KEEA district primary schools. Unpublished Ph.D. Thesis. University of Cambridge.

Oduro, G. K. T., and MacBeath, J. (2003). Traditions and tensions in leadership: The Ghana experience. Cambridge Journal of Education, 33(3): 441-455.

Ojo, L. B., and Olaniyan, D. A. (2008), Leadership roles of school administrators and challenges ahead in post-primary institutions in Nigeria. European Journal of Scientific Research, 24(2): 172-178.

Oplatka, I. (2004). The principalship in developing countries: Context, characteristics and reality. Comparative Education, 40(3): 427-448.

Pont, B., Nusche, D., and Moorman, H. (2008). Improving school leadership: Policy and practice. Paris: OECD.

Report of the President's Committee on Review of Education Reforms in Ghana (RPCRERG) (2002). Meeting the challenges of education in the twenty first century. Accra: Adwinsa Publications.

Seidu, A. (2007). Modern approaches to research in educational administration. $2^{\text {nd }}$ ed. Kumasi: Payless Publication Limited.

Simkins, T., Sisum, C., and Memon, M. (2003). School leadership in Pakistan: Exploring the head teacher's role. School Effectiveness and School Improvement, 3(2): 35-48.

Too, C., Kimutai, C. K., and Zacharriah, K. (2012). The impact of head teachers' supervision of teachers on students' academic performance. Journal of Emerging Trend in Educational Research and Policy Studies, 3(3): 299-306.
Townsend, T., (Ed.) (2007). International handbook of school effectiveness and improvement. Dordrecht, Netherlands: Springer.

Wong, S. (2005). Leadership training: perception of the impact of leadership training on newly-appointed female principals in middle/secondary schools in England and Hong Kong. Nottingham: National College for School Leadership.

Zame, M. Y., Warren, C. H., and Trimetia, R. (2008). Educational reform in Ghana: The leadership challenge. International Journal of Educational Management, 22(2): 115-128.

Citation: Suaka, P. L., and Kuranchie, A. (2018). Head teachers' professional management needs and concerns: Evidence from an educational district in Ghana. African Educational Research Journal, 6(1): 20-29. 